\title{
Kedudukan Akta Hibah dalam Sengketa Kepemilikan Hak Atas Tanah
}

\author{
Anisa Rahma Hadiyanti \\ Brawijaya University, Indonesia \\ rahmaanisa551@gmail.com \\ Rachmad Safa'at \\ Brawijaya University, Indonesia \\ rachmad.syafaat@ub.ac.id

\section{Tunggul Anshari} \\ Brawijaya University, Indonesia \\ tunggul@ub.ac.id
}

\begin{abstract}
On each social life will find a difference between behaviour with the law of norms. The discrepancy could cause dispute or tensions between each other that possibly also can happen in the family. The problems often arising during family Is the transition towards treasure in the form of grants from parents to their children. The settlement if there is a standoff over an object of the grant is forced to settle in a court. The Giving in a form of grant was conducted using an authentic deed as has been arranged in article 1682 Indonesian Civil Code. Public officials who given by statute an authority to make the deed of grants is land deed official. Related which for making such deed to as a basis for registration change as a result of a legal action the land. Related to the emergence of signs of a dispute over ownership under the grants, so In this case, every judge as milestone law enforcement have an interpretation of the difference against the rule of law in dispute resolution on the judicial process. In short, there is contradiction a norm between what has been decided by judges with the provision of article 1686 Indonesian Civil Code which the results of the uncertainty laws implementation of the article.
\end{abstract}

KEYWORDS: Deed, Grant, Property Rights, Land Rights.

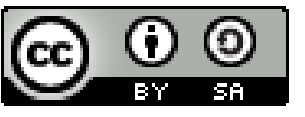

Copyright $\odot 2017$ by Author(s)

This work is licensed under a Creative Commons Attribution-ShareAlike 4.0 International License. All writings published in this journal are personal views of the authors and do not represent the views of this journal and the author's affiliated institutions.

\section{HOW TO CITE:}

Hidayanti, Anisa Rahma, Rachmad Safa'at \& Tunggul Anshari. "Kedudukan Akta Hibah dalam Sengketa Kepemilikan Hak Atas Tanah" (2017) 4:3 Lentera Hukum 213-228.

Submitted: September 07, 2017 Revised: September 17, 2017 Accepted: October 05, 2017 


\section{LATAR BELAKANG}

Hukum merupakan pencerminan dari nilai-nilai yang ada pada masyarakat. Secara umumnya ada pendapat yang menyatakan bahwa hukum yang baik seperti yang dicitacitakan oleh masyarakat sosial, maka diperlukan kaidah-kaidah (hukum) sebagai alatnya. ${ }^{1}$ Pada setiap kehidupan bermasyarakat akan dijumpai suatu perbedaan antara tingkah laku dengan hal-hal yang dikendaki oleh kaidah-kaidah hukum. Ada suatu keadaan yang tidak dapat dihindari, sehingga timbul suatu ketegangan karena terdapat perbedaan kepentingan. ${ }^{2}$ Perbedaan tersebut dapat menimbulkan perselisihan atau ketegangan satu dengan yang lainnya. Perselisihan atau ketegangan tersebut bahkan dapat pula terjadi dalam suatu keluarga. Permasalahan yang seringkali timbul dalam satu keluarga adalah berkaitan dengan harta kekayaan terutama peralihan dalam bentuk hibah dari orang tua kepada anak-anaknya.

Hibah merupakan perbuatan hukum yang bermaksud memindahkan hak kepemilikan yang sengaja dialihkan kepada pihak lain. Pemindahan hak dilakukan ketika pemegang hak masih hidup dan termasuk sebagai perbuatan hukum yang bersifat tunai, kecuali dalam hibah wasiat. ${ }^{3}$ Perbuatan hibah berbeda dengan sebuah pewarisan. Hibah terjadi pada saat seotang pemberi hibah masih hidup ketika pelaksanaan pemberian dilakukan, sedangkan pewarisan terjadi karena meninggalnya seseorang dan meninggalkan harta kekayaan. Pemberian hibah juga hanya bisa dilakukan atas benda-benda yang sudah ada. Apabila dilakukan terhadap benda-benda yang akan baru ada, maka hibah menjadi batal. ${ }^{4}$ Obyek hibah meliputi baik bendabenda bergerak maupun atas benda-benda tidak bergerak.

Pasal 1682 KUHPerdata menyebutkan bahwa pelaksanaan hibah dilakukan dengan menggunakan akta otentik. Akta otentik merupakan akta yang bentuknya telah ditentukan dalam undang-undang yang dibuat oleh dan/atau dihadapan pejabatpejabat umum yang dalam kedudukannya diberi wewenang dalam hal dimana akta itu dibuat. Akta otentik memberikan kekuatan pembuktian yang sempurna terhadap para pihak, para ahli waris maupun orang-orang yang mendapatkan hak. Akta Hibah merupakan akta otentik karena bentuknya telah ditentukan dalam suatu peraturan perundangan, dibuat Pejabat Umum yang berwenang, dan dilakukan di wilayah kerja dari Pejabat Umum yang berwenang tersebut. Bentuk yang diatur sedemikian oleh undang-undang yang disebut akta otentik terdiri dari kepala akta, badan akta, dan akhir akta. ${ }^{5}$

Pejabat Umum yang diberikan sebuah kewenangan oleh undang-undang dalam hal membuat Akta Hibah adalah Pejabat pembuat Akta Tanah setelah lahirnya Peraturan Pemerintah Nomor 24 Tahun 1997 tentang Pendaftaran Tanah, bahwa tiap

\footnotetext{
Soerjono Soekanto, Pokok-Pokok Sosiologi Hukum, (Jakarta: Raja Grafindo Persada, 2002), hlm. 14. Ibid, hlm. 19.

Boedi Harsono, Hukum Agraria Indonesia (Sejarah Pembentukan Undang-undang Pokok Agraria,Isi, dan Pelaksanaannya), (Jakarta: Djambatan, 2003), hlm. 333.

4 R. Subekti, Aneka Perjanjian, (Bandung: Citra Aditya Bakti, 1995), hlm. 95.

5 Undang-Undang Nomor 30 Tahun 2004 tentang Jabatan Notaris (Lembaran Negara Republik Indonesia Nomor 117 Tahun 2004. Tambahan Lembaran Negara Republik Indonesia Nomor 4432) Pasal 38.
} 
pemberian dalam bentuk hibah berupa tanah dan/atau bangunan harus dibuatkan secara tertulis dengan suatu akta yang dibuat oleh Pejabat Pembuat Akta Tanah sebagaimana diatur pada pasal 37 ayat (1) ${ }^{6}$ Peraturan Pemerintah Nomor 24 Tahun 1997. Pejabat Pembuat Akta Tanah diberikan kewenangan dalam pelaksana-an sebagian kegiatan dari pendaftaran tanah dengan membuat akta otentik.

Akta otentik dapat dijadikan bukti terkait adanya suatu perbuatan hukum tertentu baik mengenai suatu Hak Atas Tanah dan juga mengenai Hak Milik Atas Satuan Rumah Susun. Terkait mana pembuatan akta tersebut untuk sebagai dasar pendaftaran terkait perubahan data akibat perbuatan hukum atas tanah tersebut. Perbuatan hukum sebagaimana dimaksud adalah terkait pembuatan akta otentik oleh PPAT adalah sebagai mana diatur dalam Pasal $2^{7}$ Peraturan Pemerintah nomor 37 Tahun 1998 Tentang Peraturan Jabatan Pejabat Pembuat Akta Tanah dan perbuatan hukum tersebut haruslah dilakukan pendaftaran yang diatur pada Pasal 5 Peraturan Pemerintah Nomor 24 Tahun 1997 Tentang Pendaftaran Tanah yang mana penyelenggaraan pendaftaran tanah dilakukan Badan Pertanahan Nasional. Sedangkan terkait pelaksanaan dalam pendaftaran tanah dilakukan Kepala Kantor Pertanahan yang dibantu PPAT.

Terkait hal tersebut, Pengadilan Negeri Kepanjen yang memeriksa, mengadili dan memutus sengketa atas kepemilikan objek sengketa yang kepemilikannya berdasar pada hibah memberi putusan bahwa objek sengketa adalah sah milik dari penggugat sebagai penerima hibah. Sebagaimana disebutkan di atas bahwa PPAT sebagai profesi yang mempunyai tugas pokok untuk membantu Kantor pertanahan dan Agraria melakukan pendaftaran tanah dan pemutakhiran data yang terdapat pada Kantor Pertanahan. Suatu perbuatan hukum tidak cukup hanya dengan membuat akta saja khususnya terkait objek berupa tanah, namun harus juga dilakukan penyerahan sebagai pelaksanaan atas perjanjian yang telah disepakati. Sebagaimana di atur pada Pasal 1686 KUHPerdata yang menyatakan suatu hibah tidak beralih kepada penerima hibah selain dilakukan dengan penyerahan meskipun hibah diterima secara sah.

Akta hibah yang dapat mengesampingkan sertipikat sebagai bukti kepemilikan hak atas tanah terkait sengketa kepemilikan berdasarkan Putusan Pengadilan Negeri

6 Pasal 37 ayat (1): Peralihan hak atas tanah dan hak milik atas satuan rumah susun melalui jual beli, tukar menukar, hibah, pemasukan dalam perusahaan dan perbuatan hukum pemindahan hak lainnya, kecuali pemindahan hak melalui lelang hanya dapat didaftarkan jika dibuktikan dengan akta yang dibuat oleh PPAT yang berwenang menurut ketentuan peraturan perundang-undangan yang berlaku.

7 Pasal 2: Perbuatan hukum sebagaimana dimaksud pada ayat (1) adalah sebagai berikut:

a. Jual beli;

b. Tukar-menukar;

c. Hibah;

d. Pemasukan ke dalam Perusahaan (Inbreng);

e. Pembagian Hak Bersama;

f. Pemberian Hak Guna Bangunan/Hak Pakai atas Tanah Hak Milik;

g. Pemberian Hak Tanggungan; dan

h. Pemberian Kuasa Membebankan Hak Tanggungan. 
Kepanjen Nomor 162/Pdt.G/2012/PN.KPJ menimbulkan ketidakpastian hukum terkait implemnetasi dari Pasal 1686 KUHPerdata.

Sehingga hal tersebut berkaitan dengan letak kekuatan pembuktian akta hibah dalam sengketa kepemilikan hak atas tanah berdasarkan Putusan Pengadilan Negeri Kepanjen Nomor 162/Pdt.G/2012/PN.KPJ dan kedudukan akta hibah dalam sengketa kepemilikan hak atas tanah berdasarkan Putusan Pengadilan Negeri Kepanjen Nomor 162/Pdt.G/2012/PN.KPJ.

\section{PEMBAHASAN}

Bagian ini akan menguraikan mengenai suatu akta yang dapat digunakan sebagai bukti kepemilikan Hak Atas Tanah dalam sengketa kepemilikan yang secara khusus berdasarkan putusan Pengadilan Negeri Kepanjen Nomor: 162/Pdt.G/2012/Pn.Kpj. dan Kekuatan Pembuktian Akta Hibah Dalam Sengketa Kepemilikan Hak Atas Tanah.

\section{A. Akta Hibah sebagai Bukti Kepemilikan Hak Atas Tanah: Studi Putusan Pengadilan Negeri Kepanjen Nomor: 162/Pdt.G/2012/Pn.Kpj}

Penggugat Ni'mayani Kartikasari yang memiliki sebidang tanah pekarangan seluas 496 meterpersegi Sertipikat Hak Milik (SHM) Nomor 3109 atas nama Tergugat I Sja'bany Bachry, SH tanggal 11 Nopember 201l, Surat Ukur tanggal 11 Nopember 2011 Nomor Bidang 00040/2011, Nomor Identifikasi Tanah 12.30.18.14.03531 terletak di Jalan Raya Pakis, Desa Bunut wetan, Kecamatan Pakis, Kabupaten Malang yang diperoleh berdasarkan hibah dari Tergugat I sesuai dengan Akta Hibah Nomor : 370/PKS/RP/201l, tertanggal 28 Desember 2011, dibuat oleh dan/atau di hadapan Rachmat Praptomo, SH. Kemudian tanpa sepengetahuan Penggugat pada tanggal 26 April 2012 muncul Akta Pengikatan Jual Beli Nomor 39 antara Tergugat I dengan Tergugat II Gunawan Tri Purwanto, SH dan Kuasa Menjual Nomor 40 tertanggal 26 April 2012 dibuat oleh dan atau dihadapan Tergugat III.

Terkait hal demikian Penggugat telah melakukan upaya-upaya persuasif dengan Tergugat I, II dan III yaitu menanyakan kebenaran terkait dengan Akta Pengikatan Jual Beli Nomor 39 tertanggal 26 april 2012 dan Surat Kuasa Menjual Nomor 40 yang diperoleh klasifikasi dari Tergugat 1 yakni : Sebuah Akta Pengikatan jual beli nomor 39 tertanggal 26 April 2012 dan kuasa menjual nomor 40 yang dibuat oleh tergugat III adalah fiktif dan sama sekali tidak pernah ada transaksi atau pembayaran sejumlah uang dari tergugat II kepada Tergugat I alias jual beli bohong-bohongan. Kemudian transanksi pembayaran sebesar Rp. 276.000.000,- oleh Tergugat II kepada Tergugat I sebagaimana tercantum pada pasal 2 akta pengikatan jual beli nomor 39 sama sekali tidak pernah terjadi, seperti dihipnotis/ digendam sehingga Tergugat I menyetujui keinginan Tergugat II yang mana setelah beberapa hari kemudian sadar telah di bohongi oleh Tergugat II. Lalu Alwi dan Nurul bertemu dengan Tergugat I dikantor Tergugat I . Alwi meminta bantuan kepada Tergugat I untuk modal usaha. Alwi bermaksud mengajukan pinjaman modal ke Bank Syariah Mandiri Madiun tetapi tidak 
punya jaminan; dan Keesokan harinya Alwi dan Nurul serta seorang yang bernama Putu yang berprofesi sebagai Developer perumahan Graha Dewata datang kembali kekantor Tergugat I, saudara Putu menyatakan bersedia memberikan jaminan demi kepentingan Alwi dan Putu mempunyai 2 Sertipikat Hak Milik atas 2 unit rumah dan tanah di Perumahan Graha Dewata, namun SHM tersebut dijadikan jaminan hutang saudara Putu ke Tergugat II;

Tergugat I diminta menebus dengan sejumlah uang kepada Gunawan yaitu Rp. 276.000.000,- (dua ratus tujuh puluh enam juta rupiah) atas masing-masing sertipikat tetapi Tergugat I tidak dapat memberikan bantuan berupa uang melainkan dapat membantu dengan 2 buah sertipikat tanah kosong/Obyek Sengketa yang menurut Tergugat II harus di buatkan akta pengikatan jual beli dan kuasa menjualnya dengan kesepakatan setelah uang dari Bank Syariah Mandiri dicairkan kepada saudara Alwi maka uang tersebut dikembalikan kepada TERGUGAT I dan TERGUGAT I mendapatkan sertipikat dari Gunawan, ternyata Saudara Alwi setelah mendapat dana dari Bank Syariah Mandiri Madiun tidak menyerahkan dana tersebut ke Tergugat hingga gugatan ini dibuat.

Dalam tuntutannya, penggugat meminta kepada pengadilan salah satunya adalah menyatakan Penggugat adalah pemilik sah atas obyek sengketa dan menyatakan bahwa perbuatan Tergugat I dengan tanpa seijin penggugat mengadakan Pengikatan Jual Beli dengan Kuasa Menjual kepada Tergugat II atas Obyek Sengketa milik Penggugat adalah salah dan melawan hukum. Sedangkan Tergugat II memberikan jawaban atas klarifikasi mengenai munculnya Akta Pengikatan Jual beli nomor 39 tertanggal 26 April 2012 dan Kuasa menjual nomor 40 tertanggal 26 April 2012 Tergugat II bersedia melepas SHM rumah di Perum Graha Dewata atas nama PT. Graha dewata Abdinusa, setelah ada uang yang diterima tergugat II pada saat itu juga. Karena tidak ada uang yang tersedia, Tergugat I menawarkan tanah milik tergugat I (obyek sengketa) sebagai ganti uang. Tanah tersebut rencananya akan di beli tergugat I kembali setelah ada pencairan kredit dari BSM oleh saudara alwi. Tergugat I akan mendapat imbal jasa sebesar Rp.7,5 juta dari saudara alwi. Namun, ternyata setelah kredit dari BSM (Bank Syariah Mandiri) cair, saudara alwi tidak menyerahkan uang kepada tergugat I, sehingga tergugat I tidak bisa membeli kembali tanah (obyek sengketa) tersebut. Peristiwa ini bukan terjadi untuk pertama kali. Sebelumnya juga pada tanggal 8 februari 2012 dengan mekanisme yang sama tergugat I menawarkan bangunan ruko milik tergugat I kepada tergugat II sebagai ganti uang. Setelah kredit dari BSM (Bank Syariah Mandiri) cair, saudara Alwi segera menyerahkan uang kepada tergugat I, sehingga tergugat I dapat membeli kembali bangunan rukonya. Terkait hal ini tergugat I adalah notaris yang ditunjuk BSM untuk realisasi kredit kepada saudara Alwi. Sehingga bila tergugat I menyatakan bahwa telah dihipnotis/ditipu oleh tergugat II adalah tidak benar.

Pertimbangan hakim pengadilan Negeri Kepanjen dalam memutus sengketa Nomor: 162/Pdt.G/2012/PN.Kpj bahwa menurut pendapat majelis hakim yang menjadi pokok persoalan yang menimbulkan sengketa adalah perumusan perbuatan yang 
dilakukan Tergugat I sebagai suatu perbuatan melawan hukum atau tidak. Perbuatan melawan hukum adalah sebuah perbuatan yang dilakukan oleh seseorang dimana perbuatan yang dimaksud merugikan orang lain tetapi perbuatan itu tidak didasari oleh perjanjian, untuk dikatakan seorang melakukan perbuatan melawan hukum harus dipenuhi syarat-syarat seperti harus ada perbuatan, perbuatan harus melawan hukum, ada kerugian, ada hubungan sebab akibat antara perbuatan melawan hukum dan kerugian serta kesalahan. Sejak diperluasnya pengertian perbuatan melawan hukum dengan tidak hanya melanggar undang-undang saja namun diartikan pula melanggar hak subjektif orang lain, kewajiban hukum pelaku, kaedah kesusilaan dan kepatutan dalam masyarakat. Terkait demikian berdasarkan Standaard Arest Tahun 1919, berbuat atau tidak berbuat merupakan suatu perbuatan melawan hukum jika $:^{8}$ terbukti perbuatan melanggar undang-undang dan melanggar hak subjektif orang lain, berarti melanggar sebuah wewenang khusus yang diberikan hukum kepada tiap-tiap orang. Yurisprudensi memberikan pengertian atas hak subjektif diantaranya bahwa: Hak-hak perorangan berupa kebebasan, kehormatan, nama baik Hak atas harta kekayaan, berupa hak kebendaan dan hak mutlak lainnya.

Pelanggaran atas hak subjektif orang lain tersebut dapat dikategorikan sebagai perbuatan bersifat melawan hukum apabila perbuatan tersebut langsung melanggar atas hak subjektif orang lain berdasarkan pandangan dewasa ini disyaratkan adanya sebuah pelanggaran atas tingkah laku, sesuai hukum tertulis maupun tidak tertulis yang seharusnya tidak dilanggar oleh pelaku dan tidak ada sebuah alasan pembenar menurut hukum dan bertentangan terhadap kewajiban hukum pelaku. Kewajiban hukum mana diartikan sebagai kewajiban berdasarkan hukum, baik hukum tertulis maupun tidak tertulis (termasuk tindak pidana berupa pencurian, penggelapan dan pengrusakan). Seperti Bertentangan dengan suatu kaedah kesusilaan, yakni bertentangan terhadap norma-norma moral, sepanjang diakui sebagai suatu norma hukum dalam sebuah kehidupan masyarakat. Kemudian bertentangan dengan asas kepatutan dalam lau lintas kehidupan masyarakat terhadap diri dan orang lain. Terkait hal ini haruslah dipertimbangkan antara kepentingan sendiri dan kepentingan orang lain dengan mengikuti kepatutan yang menurut masyarakat patut dan layak.

Beberapa definisi lain atas perbuatan melawan hukum diantaranya sebagai berikut: ${ }^{9}$ Perbuatan melawan hukum tidak memenuhi sesuatu yang menjadi kewajibannya selain dari kewajiban kontraktual atau kewajiban quasi contractual yang menerbitkan hak untuk meminta ganti rugi. Suatu perbuatan yang berbuat atau tidak berbuat yang menimbulkan akibat kerugian bagi orang lain tanpa sebelumnya ada suatu hubungan hukum yang mana perbuatan atau tidak berbuat tersebut.

Tidak terpenuhinya suatu kewajiban yang dibebankan hukum, kewajiban mana yang ditujukan kepada tiap-tiap orang pada umumnya, dan dengan tidak terpenuhinya kewajiban tersebut dapat dimintakan sebuah ganti kerugian. Suatu kesalahan perdata

8 R. Setiawan, Empat Kriteria Perbuatan Melawan Hukum dan Perkembangan dalam Yurisprudensi, Varia Peradilan No. 16 Tahun II (Januari 1987), hlm. 176.

9 Munir Fuady, Hukum Kontrak (dari sudut pandang hukum bisnis), (Bandung: Citra Aditya Bakti, 1999), hlm. 4 . 
(civil wrong) dalam hal mana ganti kerugian dapat dituntut yang bukan merupakan wanprestasi terhadap kontrak atau wanprestasi terhadap kewajiban trust ataupun wanprestasi terhadap kewajiban equity lainnya. Suatu kerugian yang timbul bukan disebabkan oleh perbuatan wanprestasi terhadap kontrak, merupakan suatu perbuatan yang menimbulkan kerugian bagi hak-hak orang lain yang tidak terbit dari sebuah hubungan kontraktual dan sesuatu perbuatan atau tidak berbuat secara bertentangan dengan hukum yang melanggar hak orang lain dan karenanya dapat dituntut ganti kerugian oleh pihak yang merasa dirugikan seperti perbuatan melawan hukum bukan suatu kontrak seperti halnya kimia yan bukan pula fisika atau matematika.

Untuk mengetahui apakah perbuatan yang dilakukan Tergugat I termasuk perbuatan melawan hukum adalah dengan memperhatikan syarat-syarat materiil yang harus dipenuhi secara keeluruhan agar suatu perbuatan dapat dikategorikan sebagai suatu perbuatan melawan hukum sehingga dapat dijadikan dasar untuk menuntut ganti kerugian. Berdasar pada bukti-bukti dalam kasus sengketa antara Penggugat dengan Tergugat I serta dengan merujuk pada ketentuan pada Pasal 1365 KUHPerdata di bawah ini akan diuraikan apakah perbuatan Tergugat I memenuhi unsur perbuatan melawan hukum : (1) Adanya suatu perbuatan yang mana perbuatan yang dimaksud tidak hanya perbuatan yang aktif, namun juga meliputi perbuatan yang bersifat pasif. Perbuatan aktif atau yang disebut juga dengan perbuatan yang positif merupakan perbuatan yang dengan positif dilakukan oleh seseorang dengan sengaja dan perbuatan yang pasif atau negatif adalah dengan tidak melakukan suatu perbuatan, dapat menimbulkan kerugian bagi orang lain.

Tergugat I dalam hal ini yang mengadakan perjanjian lain dengan Tergugat II atas objek sengketa yang telah terlebih dahulu dihibahkan kepada anaknya Penggugat adalah tidak termasuk sebagai perbuatan yang melawan hukum. Perbuatan Tergugat I dalam hal ini adalah tidak memenuhi prestasi sebagai kewajibannya untuk melaksanakan prosesi hibah secara sempurna sebagaimana dimaksud dalam undangundang yakni tidak diserahkannya hak kebendaan hibah kepada penerima hibah setelah memberikan janji untuk menghibahkan objek sengketa yang telah dituangkan dalam Akta Hibah Nomor : 370/PKS/RP/2011.

Terkait demikian timbulnya hak dan kewajiban yang tercipta antara Tergugat I dengan Penggugat adalah berasal dari hubungan keperdataan yang didasarkan atas perbuatan hukum hibah sebagai perjanjian cuma-cuma yang menimbulkan kewajiban pelaksanaan prestasi juga bersifat sepihak yakni ada pada pemberi hibah untuk memberikan suatu hak kebendaan tanpa syarat kepada penerima hibah dan hak dari penerima hibah adalah menerima hak kebendaan yang diberikan oleh pemberi hibah. Terkait hal tersebut, dapat dilihat bahwa dalam pelaksanaan perjanjian yang bersifat sepihak dalam perbuatan hibah adalah Tergugat I tidak memiliki itikad baik untuk memenuhi prestasi yang ditimbulkan atas perjanjian hibah yang telah dibuat secara akta otentik dengan Penggugat.

Pasal 1234 KUHPerdata mengatur terhadap tiap-tiap perikatan diantaranya 
untuk memberikan sesuatu, untuk berbuat sesuatu, dan untuk tidak berbuat sesuatu. Pada perbuatan hibah adalah sebagai salah satu bentuk dari prestasi untuk memberikan sesuatu. Sedangkan, jika salah satu pihak tidak memenuhi sebuah prestasi kepada pihak lain, maka perbuatan pihak tersebut termasuk perbuatan wanprestasi sebagaimana diatur pada Pasal 1236 KUHPerdata.

Pengertian perbuatan melawan hukum perbuatan yang melawan hukum seperti dalam ketentuan Pasal 1365 KUHPerdata selain perbuatan melanggar undang-undang juga meliputi perbuatan yang bertentangan dengan kewajiban hukum sendiri dan kesusilaan. Suatu perbuatan dapat dikatakan sebagai perbuatan yang melawan hukum apabila : Melanggar hak subjketif orang lain, yakni melanggar wewenang khusus menurut hukum diberikan kepada seseorang seperti hak perorangan dan hak atas harta kekayaan/kebendaan dan bertentangan dengan sebuah kewajiban hukum pelaku, yakni perbuatan yang dilakukan bertentangan dengan undang-undang baik berupa keharusan, larangan, tertulis maupun tidak tertulis. Kemudian pertentangan dengan kepatutan, ketelitian dan kehati-hatian yang berkaitan dengan akhlak pribadi sebagai manusia. Bertentangan dengan kepatutan dalam masyarakat yang dapat merugikan orang lain serta perbuatan tidak berguna yang menimbulkan sebuah bahaya bagi orang lain, berdasar pada pemikiran normal.

Pemberian hibah yang dilakukan oleh Tergugat I kepada Penggugat tidak dilaksanakan secara sempurna sebagaimana peraturan perundang-undangan yang mengatur mengenai hibah yakni dengan tidak diberikannya hak kepada penerima hibah secara penuh untuk menguasai, memanfaatkan objek tanah yang diberikan melalui hibah tersebut. Artinya pelanggaran yang dilakukan Tergugat tersebut bukan sebagai pelanggaran terhadap hak subjektif sebagaimana dimaksud dalam suatu perbuatan melawan hukum.

Hal demikian dikarenakan hak subjektif yang dimaksud dalam perbuatan melawan hukum adalah hak yang diberikan oleh hukum secara langsung, sedangkan hak bagi penerima hibah diberikan karena didasarkan atas adanya perjanjian mengenai perbuatan hukum untuk memberikan hak atas kebendaan kepadanya yang mana pemberian dalam bentuk hibah juga dilindungi secara hukum terkait pelaksanannya. Sehingga dapat dikatakan perbuatan yang dilakukan oleh Tergugat I adalah suatu perbuatan wanprestasi karena tidak dilaksanakannya prestasi yang ditimbulkan atas dibuatnya perjanjian hibah tersebut.

Adanya Kesalahan yang terjadi apabila seorang pelaku tidak berkeinginan menimbulkan akibat, tetapi ketika perbuatan dilakukan dengan tidak mengupayakan kehati-hatian sehingga akibat yang tidak diinginkan tersebut terjadi. Terkait kasus dalam sengketa ini, perbuatan Tergugat I bisa dikatakan merupakan suatu kesalahan dikarenakan profesinya sebagai seorang Notaris dan PPAT seharusnya sudah faham bagaimana prosedur dan tata cara dalam melaksanakan suatu perjanjian khususnya hibah.

Adanya kerugian yang ditimbulkan sebagai akibat perbuatan melawan hukum berupa kerugian materiil sebagai sebuah kerugian yang secara nyata diderita dari 
keuntungan yang seharusnya diperolehnya serta kerugian moril yang mempunyai sifat idiil berupa timbulnya rasa sakit dan kehilangan kesenangan hidup. Sesuai dengan persyaratan yang seharusnya dipenuhi guna menyatakan sebuah perbuatan termasuk perbuatan melawan hukum, maka terkait uraian di atas, sehingga dapat dikatakan bahwa perbuatan Tergugat I bukan perbuatan yang melawan hukum namun perbuatan wanprestasi dengan tidak melaksanakan prestasi untuk memberikan sesuatu. Tidak dipenuhinya kewajiban dan atau prestasinya, terhadap pemenuhan prestasi Penggugat mempunyai hak untuk menuntut pelaksanaannya. guna mengetahuisejak kapan debitur itu dalam keadaan wanprestasi maka perlu diperhatikan apakah di dalam perikatan yang disepakati tersebut ditentukan atau tidak tenggang pelaksanaan pemenuhan prestasi.

Terkait perjanjian untuk memberikan sesuatu atau melakukan sesuatu maka pihak-pihak dapat menentukan dan juga tidak menentukan terhadap tenggang waktu dalam pelaksanaan pemenuhan prestasi oleh debitur. ${ }^{10}$ Terkait tenggang waktu tidak ditentukan maka dipandang perlu untuk memperingatkan debitur guna memenuhi prestasinya tersebut dan dalam hal tenggang waktu pelaksanaan pemenuhan prestasi ditentukan maka menurut ketentuan Pasal 1238KUHPerdata debitur dianggap lalai dengan lewatnya waktu yang ditentukan. ${ }^{11}$ Dasar perjanjian adalah sebuah kesepakatan diantara para pihak yang menimbulkan sebuahprestasi, apabila salah satu pihak tidak memenuhi prestasi dalam perjanjian akan menimbulkan ingkar janji (wanprestasi) jika memang dapat dibuktikan bukan karena overmacht atau keadaan memaksa. dapun yang dimaksud wanprestasi adalah suatu keadaan yang dikarenakan kelalaian atau kesalahannya, debitur tidak dapat memenuhi prestasi seperti yang telah ditentukan dalam perjanjian. ${ }^{12}$

Perikatan lahir dapat dikarenakan suatu perjanjian, dalam hal dari perjanjian merupakan suatu pertemuan kehendak para pihak yang berjanji akan menimbulkan prestasi. Arti prestasi sendiri dapat dilihat dari Pasal 1234 KUHPerdata menyebutkan bahwa tiap-tiap perikatan adalah memberikan sesuatu, berbuat sesuatu, atau tidak berbuat sesuatu. Kata memberikan sesuatu sebagaimana disebutkan di dalam Pasal 1235 KUHPerdata tersebut dapat mempunyai dua pengertian, yaitu: sebuah penyerahan kekuasaan atas barang obyek perjanjian dan penyerahan hak milik atas barang obyek perjanjian, yang disebut penyerahan yuridis.

Pasal 1686 KUHPerdata sebagai pelaksanaan hibah telah mengatur bahwa hak milik atas benda-benda yang termaktub atau tercantum dalam sebuah penghibahan, sekalipun telah diterima dengan sah, tidaklah serta merta berpindah, selainnya dengan jalan penyerahan menurut Pasal 612, 613, 616 KUHPerdata dan selanjutnya. Artinya bahwa meskipun ada kesepakatan mengenai hibah, tidak secara otomatis benda yang dialihkan berpindah kepada si penerima hibah. Namun, masih harus dilakukan sebagaimana ketentuan-ketentuan pada pasal-pasal tersebut di atas, terlebih harus ada

10 Abdul Kadir Muhammad, Hukum Perdata Indonesia (Bandung: Citra Aditya Bhakti, 2000), hlm. 21

$11 \quad$ Ibid, hlm. 22.

12 Nindyo Pramono, Hukum Komersil (Jakarta: Pusat Penerbitan UT, 2003), hlm. 221. 
penyerahan nyata terhadap benda bergerak yang dilakukan oleh pemilik, kemudian penyerahan benda tak bertubuh yakni dengan membuat akta otentik atau akta di bawah tangan dengan melakukan pengumuman atas penyerahan tersebut dan alinan akta otentik harus didaftar dalam buku register.

Suatu hak atas tanah dapat dialihkan atau diperalihkan. Peralihan hak atas tanah dilakukan oleh pemilik hak atas tanah sendiri. Seseorang dikatakan sebagai pemilik dari hak atas tanah dapat diketahui dari bukti kepemilikan hak atas tanah yang dimilikinya. Bukti atas kepemilikan hak atas tanah ini dapat diketahui melalui sertipikat hak atas tanah. Terkait unsur-unsur pemilikan atas tanah, maka hak pemilikan atas tanah merupakan hak terpenting yang dapat dimiliki tiap warga ngara atas sebidang tanah. Hak mana yang memberikan kesempatan bagi pemegang hak untuk memanfaatkan atau mengusahakan tanah yang dimilikinya demi kesejahteraan, yang dalam hal penguasaan mana tidak boleh bertentangan dengan ketentuan perundang-undangan.

Terkait hubungan pemilikan tanah pada UUPA diartikan sebagai penguasaan atas tanah yang didasarkan atas suatu hak baik dengan status berupa hak milik, Hak Guna Usaha, Hak Guna Bangunan, Hak pengelolaan, dsb. Menurut C.B Macpheron, hakekat sebuah kepemilikan bahwa kepemilikan adalah sebagai sebuah hak dalam arti klaim yang mana dapat dipaksakan, sifat klaim yang dapat dipaksakan tersebut menjadikan hak sebagai hak menurut hukum, namun ciri yang dapat dipaksakannya tergantung keyakinan dari masyarakat bahwa itu adalah sebuah moral. ${ }^{13}$ Kepemilikan adalah hak bukan barang. Kepemilikan adalah tuntutan yang dapat dipaksakan yang diciptakan negara.

Kepastian hukum mengenai data kepemilikan tanah akan tercapai apabila dilakukan Pendaftaran Tanah, karena dasar tujuan Pendaftaran Tanah adalah untuk memberikan jaminan kepastian hukum dan perlindungan hukum kepada pemegang hak atas tanah. Baik kepastian mengenai subyeknya (yaitu apa haknya, siapa pemiliknya, ada / tidak beban diatasnya) dan kepastian mengenai obyeknya, yaitu letaknya, batas-batasnya dan luasnya serta ada/ tidaknya bangunan / tanaman diatasnya. Berdasarkan Pasal 32 ayat (1) Peraturan Pemerintah Nomor 24 Tahun 1997 Tentang Pendaftaran Tanah, menyatakan bahwa sertifikat sebagai surat tanda bukti hak berlaku sebagai alat pembuktian yang kuat mengenai sebuah data fisik dan data yuridis sepanjang data-data tersebut sesuai dalam surat ukur dan buku tanah hak yang bersangkutan.

Dalam rangka pemberian jaminan suatu kepastian hukum, kepada pihak yang melakukan pendaftaran tanahnya akan diberikan satu dokumen sebagai tanda bukti hak yang bersifat kuat dan luas. Sertipikat sebagai salinan buku tanah hasil akhir dari sebuah proses penyelidikan dari riwayat penguasaan suatu bidang tanah dengan meneliti surat-surat buktinya, yang setelah melalui syarat tertentu akan merupakan alas hak pada pendaftaran pertama dan peralihan hak berikutnya. Alat bukti kuat yang melekat pada sertifikat, artinya selama pihak lawan tidak dapat membuktikan

13 Macpherson C.B., Pemikiran Dasar Tentang Hak Milik (Jakarta: Yayasan LBH Indonesia, 1978), hlm. 14. 
sebaliknya maka sebuah sertipikat harus dianggap sebagai suatu alat bukti yang sempurna/cukup. ${ }^{14}$ Contoh bukti lain yang melemahkan kekuatan pembuktian dari suatu sertipikat hak atas tanah tersebut adalah keputusan Pengadilan Negeri yang telah berkekuatan hukum tetap, yang menetapkan bahwa tanah tersebut adalah hak penggugat yang menang, atau putusan Pengadilan yang berkekuatan hukum tetap yang membatalkan sertipikat tersebut atau menyatakan bahwa sertipikat tersebut tidak berkekuatan hukum tetap.

\section{B. Kekuatan Pembuktian Akta Hibah Dalam Sengketa Kepemilikan Hak Atas Tanah}

Kekuatan pembuktian yang sempurna pada sebuah akta otentik merupakan perpaduan dari beberapa kekuatan pembuktian dan persyaratan yang terdapat padanya. Ketiadaan salah satu kekuatan pembuktian ataupun persyaratan tersebut akan mengakibatkan suatu akta otentik tidak mempunyai nilai kekuatan pembuktian yang sempurna dan mengikat sehingga akta akan kehilangan keotentikannya dan tidak lagi menjadi akta otentik.Suatu Akta hibah pembuktian yang sah, bilamana proses pembuatan Akta hibah memenuhi syarat-syarat sebagai berikut: a)dibuat oleh (door) atau dihadapan pejabat umum, b) dibuat dalam bentuk yang ditentukan oleh aturan undang-undang c) pejabat umum oleh atau dihadapan siapa akta itu dibuat, harus mempunyai wewenang untuk membuat akta.

Dalam sebuah akta otentik harus memenuhi kekuatan pembuktian lahiriah, formil dan materil,yaitu: ${ }^{15}$ kekuatan pembuktian lahiriah, menurut Efendi, Bachtiar dkk, kekuatan pembuktian secara lahiriah adalah sesuai dengan asas "acta publica probant seseipsa" yang berarti suatu akta yang lahirnya tampak sebagai akta otentik serta memenuhi syaratsyarat yang telah ditentukan maka akta itu berlaku atau dianggap sebagai akta otentik sampai dapat dibuktikan sebaliknya dan kekuatan Pembuktian Formil, dalam hal mana secara formil, suatu akta otentik menjamin kebenaran dan kepastian hari, tanggal, bulan, tahun, pukul (waktu) menghadap, dan para pihak yang menghadap, tanda tangan para pihak, notaris dan saksi dan tempat akta dibuat. Dalam arti formil pula akta notaris membuktikan kebenaran dari apa yang disaksikan yaitu yang dilihat, didengar dan dialami sendiri oleh notaris sebagai Pejabat Umum dalam menjalankan jabatannya.

Kekuatan Pembuktian Materiil, adalah terkait kepastian tentang materi isi suatu akta, bahwa apa yang tersebut dalam akta merupakan pembuktian yang sah terhadap pihak-pihak yang membuat akta. Keterangan yang disampaikan penghadap kepada notaris dituangkan dalam akta dinilai telah benar. Berdasarkan Pasal 165 HIR, akta memilki unsur-unsur seperti tulisan yang memuat fakta, peristiwa, atau keadaan yang menjadi dasar dari suatu hak atau perikatan Yang ditandatangani oleh para pihak yang bersangkutan dengan maksud untuk menjadi bukti.

Sertipikat adalah buku tanah dan surat ukurnya setelah dijilid menjadi satu berma-sama dengan suatu kertas sampul yang bentuknya ditetapkan dengan peraturan

14 Urip Santoso, Pendaftaran dan Peralihan Hak atas Tanah. Cet. 2, (Jakarta: Kencana, 2010), hlm. 45.

15 G.H.S. Lumbang Sutobing, Peraturan Jabatan Notaris (Jakarta: Erlangga, 1983), hlm. 54. 
pemerintah. Kekuatan Pembuktian sebuah Sertipikat, terdiri dari: Sistem Positi, bahwa sebuah sertipikat tanah diberikan sebagai tanda bukti hak atas tanah yang bersifat mutlak serta merupakan satu-satunya tanda bukti hak dan Sistem Negatif, bahwa halhal yang tercantum pada sebuah sertifikat harus dianggap benar sampai dapat dibuktikan sebaliknya (tidak benar) dimuka sidang pengadilan.

Suatu akta otentik sebagai alat bukti sempurna mengenai sesuatu yang termuat didalamnya sebagai penuturan belaka, selainnya sekadar sesuatu yang dituturkan itu ada hubungannya langsung dengan pokok isi akta, dari pasal tersebut diambilah mengenai segala sesuatu yang menjadi pokok isi akta itu, yaitu segala sesuatu yang tegas dinyatakan oleh para penandatanganan akta.Akta otentik tidak hanya mempunyai kukuatan pembuktian formal, yaitu bahwa benar para pihak sudah menerangkan sesuatu yang ditulis dalam akta tersebut, tetapi juga mempunyai kekuatan pembuktian materiil, yaitu bahwa sesuatu yang diterangkan tadi adalah benar, inilah yang dinamakan kekuatan pembuktian mengikat, disimpulkan bahwa kekuatan pembuktian akta otentik, adalah sah dengan melengkapi bukti sempurna/lengkap terhadap para pihak, ahli waris dan orang-orang yang mendapatkan hak dari padanya, bukti sempurna /lengkap berarti bahwa kebenaran dari isi akta tersebut harus diakui, tanpa ditambah dengan pembuktian lain, sampai dapat dibuktikan sebaliknya oleh pihak lain tersebut kemudian bukti yang bebas bagi pihak ketiga, artinya bahwa kebenaran isi akta diserahkan kepada penilaian oleh hakim, jika dapat dibuktikan sebaliknya.

Terkait kekuatan pembuktian di atas, dapat disimpulkan bahwa tiap akta notaris mempunyai tiga macam kekuatan pembuktian, yaitu : ${ }^{16}$ (1) Kekuatan pembuktian luar (uitwendige bewijskracht), ialah persyaratan formal yang diperlukan dalam pembuatan akta notaris sehingga dapat berlaku sebagai akta otentik. (2) Kekuatan pembuktian formal (formale bewijskracht), ialah kepastian adanya sebuah kejadian yang dalam akta benar dilakukan oleh Notaris atau berdasarkan keterangan pihak-pihak yang menghadap. (3) Kekuatan pembuktian materiil (materiele bewijskracht), ialah kepastian mengenai apa yang tersebut dalam sebuah akta itu merupakan pembuktian yang sah terhadap pihak-pihak yang membuat akta atau mereka yang mendapat hak dan berlaku untuk umum, kecuali dapat dibuktikan sebaliknya (tegenbewijs).

Akta otentik sebagai alat bukti yang memiliki kekuatan pembuktian sempurna terhadap kedua belah pihak dan ahli warisnya serta sekalian orang yang mendapat hak darinya tentang apa yang dimuat dalam akta tersebut. Akta Otentik merupakan bukti yang mengikat yang berarti kebenaran dari hal-hal yang tertulis dalam akta tersebut harus diakui oleh hakim, yaitu akta tersebut dianggap sebagai benar selama kebenarannya itu tidak ada pihak lain yang dapat membuktikan sebaliknya. Akta Hibah sebagai akta otentik yang diajukan oleh penggugat dalam sengketa pada Pengadilan Negeri Kepanjen tetap mempunyai kekuatan pembuktian yang sempurna karena pihak tergugat I sebagai pemberi hibah yang tercantum pula pada akta tersebut

16 Habib Adjie, Sanksi Perdata Dan Administratif Terhadap Notaris Sebagai Pejabat Publik, Cet. 2 (Bandung: Refika Aditama, 2009) hlm. 72-74. 
tidak menyangkal atas kebenaran mengenai hal-hal yang tercantum didalamnya.

\section{Kedudukan Akta Hibah Dalam Sengketa Kepemilikan Hak Atas Tanah}

Pembuatan Akta PPAT oleh seorang pejabat umum harus dihadiri oleh para pihak atau kuasanya dan disaksikan oleh minimal 2 orang saksi yang layak guna menyaksikan adanya perbuatan hukum atas tanah. Akta PPAT dibuat dalam 2 rangkap asli, 1 rangkap disimpan dalam kantor PPAT yang bersangkutan, 1 rangkap disampaikan kepada kantor pertanahan kabupaten/kota setempat untuk keperluan pendaftran dan kepada pihak yang bersangkutan diberikan salinannya. Pembuatan akta tanah sebagai bentuk konsensus guna mengalihkan hak atas tanah bagi para pembuat perjanjian memiliki fungsi, diantaranya terhadap tanah bersertifikat, bertujuan mendaftarkan peralihan hak atas tanah. Dengan lain perkataan bahwa akta tanah berfungsi sebagai alas hak pada proses balik nama sertifikat hak atas tanah;

Terhadap tanah yang belum bersertifikat akta berfungsi sebagai alas hak dalam rangka permohonan penerbitan hak baru; dan untuk memberikan kepastian hukum dan perlindungan hukum kepada pemegang hak atas sebuah bidang tanah agar dapat dengan mudah membuktikan dirinya sebagai pemegang hak atas tanah, kemudian untuk menyediakan informasi bagipihak-pihak yang berkepentingan termasuk pemerintah agar dengan mudah dapat memperoleh datayang diperlukan dalam mengadakan perbuatan hukum mengenai bidang-bidang tanah yang sudah terdaftar untuk terselenggaranya tertib administrasi pertanahan.

Alas hak dengan hak atas tanah adalah dua hal yang berbeda. Alas hak merupakan salah satu syarat bagi warga negara untuk mengajukan permohonan hak atas tanah, seperti jual beli, hibah, waris, atau penguasaan fisik selama puluhan tahun. Namun alas hak itu sendiri bukan hak atas tanah. Hak atas tanah merupakan pendaftaran hubungan hukum kepemilikan tanah antara subjek hukum dengan objek hukum, yang dicatat pejabat pertanahan pada buku tanah yang menjadi dasar bagi terbitnya sertifikat hak atas tanah, sebagai tanda bukti hak kepemilikan.

Sengketa tanah kerap terjadi karena status kepemilikan. Permasalahan akan muncul jika status kepemilikan dikemudian hari berpindah tangan, baik itu melalui jual beli maupunwarisan ataupun hibah. Permasalahan mengenai tanah muncul dikarenakan ketidaktahuan dan ketidakpedulian si pemilik tanah terhadap status tanah yang dimilikinya. Maksudnya bahwa pemilik tidak mendaftarkan tanah kepada institusi yang berwenang yakni Kantor Pertanahan ataupun Badan Pertanahan Nasional. Suatu sertifikasi tanah sangat penting mengenai keabsahannya (legalitas) di mata hukum. Adanya sebuah sertifikat tanah, legalitasnya akan menjadi kuat dan sah. Pemilik tanah juga tidak akan merasa khawatir terhadap harta (tanah) yang dimilikinya.

Layaknya dengan harta lainnya, tanah perlu mendapatkan sebuah pengakuan secara hukum oleh negara. Guna terwujudnya jaminan kepastian hukum di bidang pertanahan terdapat dua hal yang harus diperhatikan, yakni perlu adanya hukum tanah yang tertulis dan penyelenggaraan pendaftaran tanah. Secara sederhana, kegiatan 
pendaftaran tanah mempunyai dua tujuan diantaranya pemberian jaminan kepastian hukum dan kepastian hak atas tanah. Terkait hal demikian, penyelenggaraan pendaftaran tanah, ada dua kepentingan (pihak) yangdilindungi. Pertama, kepentingan pemegang hak atas tanah yang merupakan sebagai wujud dari kepastian hukum, pemilik tanah akan mendapat bukti pendaftaran tanahnya berupa sertifikat. Kedua, kepentingan terhadap pihak lain, yakni calon pembeli dan calon kreditur. Hal tersebut bertujuan, agar dapat dengan mudah diperolehnya data yang dipercayai kadar kebenarannya.

Hibah yang mempunyai arti pemberian atau sedekah, yang mengandung makna yaitu suatu persetujuan pemberian barang yang didasarkan atas rasa tanggung jawab sesamanya dan dilaksanakan dengan penuh keihklasan tanpa pamrih apapun. Pengertian hibah menurut Pasal 1666 KUHPerdata ialah suatu perjanjian dengan mana penghibah, di waktu hidupnya, dengan cuma-cuma dan dengan tidak dapat ditarik kembali, menyerahkan sesuatu benda guna keperluan penerima hibah yang menerima penyerahan itu. Undang-Undang tidak mengakui lain-lain hibah di antara orang yang masih hidup. Oleh dikarenakan hibah ditentukan dengan undang-undang sebagai suatu persetujuan, dengan sendirinya hibah wajib menimbulkan konsekuensi hukum yakni pemberi hibah wajib menyerahkan dan memindahkan barang yang dihibahkan kepada penerima hibah.

Hibah menimbulkan hubungan hukum diantara pemberi hibah dengan penerima hibah meskipun hubungan tersebut merupakan hubungan yang bersifat sepihak (pemberi hibah memberikan barang hibah kepada penerima hibah secara cuma-cuma dan tanpa meminta imbalan apapun).Hal tersebut berarti pemberi hibah hanya memiliki kewajiban saja tanpa memiliki hak. Berdasarkan teori kepastian hukum maka kedudukan akta hibah dalam kasus tersebut merupakan akta autentik yang sah yang peruntukkannya untuk bukti awal peralihan hak atas tanah yang digunakan oleh Penggugat. Dalam hal mana keberadaannya dapat menjamin dengan jelas kepemilikan atas obyek sengketa dalam penelitian ini.menjamin dengan jelas kepemilikan atas obyek sengketa dalam penelitian ini.

Berdasarkan Undang-undang Nomor 5 tahun 1960 tentang Peraturan Dasar Pokok-pokok Agraria yang selanjutnya disingkat dengan UUPA, dalam pasal 19 dinyatakan bahwa untuk terciptanya kepastian hukum dalam bidang pertanahan, pemerintah menyelenggarakan sebuah program pendaftaran tanah, dalam hal mana tanah yang telah didaftarkan selanjutnya akan diberikan sebuah tanda bukti hak atas tanah, sebagai alat bukti yang kuat mengenai kepemilikan tanah. Mengenai pengalihan atau penyerahan hak atas tanah, terdapat dua pendapat yaitu yang pertama adalah bahwa jual beli harus dilakukan dengan akta otentik yang diikuti dengan pendaftaran tanah untuk mendapatkan sertifikat sebagai tanda bukti hak atas tanah.

Akta otentik yang dibuat Pejabat Pembuat Akta Tanah, bukan saja hanya sebagai alat bukti untuk pendaftaran tetapi merupakan syarat mutlak adanya perjanjian penyerahan. Pendapat ini diwakili oleh Mariam Darus Badrulzaman dan Saleh Adiwinata. Mariam Darus Badrulzaman berpendapat, bahwa lembaga pendaftaran, 
tidak semata-mata mengandung arti untuk memberikan alat bukti yang kuat, akan tetapi juga menciptakan hak kebendaan. Hak kebendaan atas suatu benda tanah terjadi pada saat pendaftaran dilakukan. Sebelum dilakukan pendaftaran yang ada baru milik, belum hak. Dalam kaitan itulah, maka salah satu asas penting pada hak atas tanah adalah asas publisitas. Pendapat yang dianut Mariam Darus Badrulzaman di atas, tampaknya sangat dipengaruhi oleh ajaran teori causal, yang memandang bahwa hubungan hukum adalah obligatoirnya, sedangkan levering adalah akibatnya. Artinya levering baru sah, dan karenanya baru menjadikan yang menerima penyerahan sebagai pemilik, kalau rechtstitel yang memindahkan hak milik sah.

Peraturan Pemerintah No. 24 tahun 1997 tentang Pendaftaran Tanah mempunyai sifat stelsel pasif, artinya yang didaftar adalah hak, peralihan hak dan penghapusannya serta pencatatan beban-beban atas hak dalam daftar buku tanah. Hubungan antara pemindahan dengan alas hak adalah bersifat kausal, karena sifat peralihan hak tersebut adalah bersifat levering. Stelsel negatif ini berakibat pada buku tanah tidak memberikan jaminan yang mutlak, peranan yang pasif dari pajak balik nama, artinya pejabat-pejabat pendaftaran tanah tidak berkewajiban untuk menyelidiki kebenaran dari dokumen-dokumen yang diserahkan kepada mereka.

Di sisi lain, terdapat teori abstraksi yang menganut adanya pemisahan antara levering dengan rechtstitel. Jadi kalau sekiranya ada suatu penyerahan, dimana yang melakukan penyerahan tidak memiliki titel, penyerahan tersebut tetap sah. Pemilik asal tidak dapat menuntut hak kebendaan dari pihak ketiga, yang membeli dengan itikad baik. Tuntutan pemilik asal adalah tuntutan pribadi terhadap orang yang mengalihkan hak kepada pihak ketiga tadi tanpa hak. Pandangan para pakar di atas sangat menentukan dalam hal ada dua kepemilikan atas objek yang sama untuk menentukan pemilik dan pemegan hak yang sesungguhnya.

Berdasarkan landasan teori tersebut di atas, apabila dilihat dari transaksi hibah atas ojek tanah, dapat diberikan analisis sebagai berikut kemudian sebagai transaksi hibah tanah antara Tergugat I dengan Penggugat adalah sah, transaksi hibah tanah antara Tergugat I dengan Penggugat, yang tidak atau belum dilanjutkan dalam proses pendaftaran tanah guna memperoleh tanda bukti hak berupa sertifikat tanah, membawa akibat hukum bahwa bukti kepemilikan Penggugat atas tanah tersebut belum lengkap, Akta hibah berdasarkan akta otentik adalah sah, sepanjang menyangkut penyerahannya. Dengan demikian, kepemilikan yang dipunyai Penggugat adalah kepemilikan yang bersifat kebendaan, bukan kepemilikan yang bersifat hak perorangan, Gugatan yang dikabulkan oleh Pengadilan Negeri Kepanjen, sifatnya adalah berupa pemulihan hak kebendaan atas tanah. Guna memperoleh hak milik, maka Penggugat haruslah melanjutkan dengan prosedur normal yakni dengan melakukan pendaftaran tanah untuk mendapatkan sertifikat sebagai tanda bukti hak. 


\section{KESIMPULAN}

Sertipikat sebagai salinan dari buku tanah yang merupakan hasil akhir dari suatu proses penyelidikan riwayat penguasaan bidang tanah dengan meneliti surat-surat buktinya, yang setelah melalui syarat tertentu akan merupakan alas hak pada pendaftaran pertama dan peralihan-peralihan hak berikutnya. Terkait mana Akta otentik sebagai syarat dalam melakukan pendaftaran merupakan sebuah alat dengan pembuktian sempurna bagi dua belah pihak dan ahli warisnya serta sekalian orang yang mendapat hak darinya tentang apa yang dimuat dalam akta tersebut. Namun kekuatan pembuktian atas akta terhadap pihak ketiga adalah bebas, merupakan bukti bebas bagi pihak ketiga, karena kebenaran dari isi akta diserahkan pada penilaian hakim, jika dapat dibuktikan sebaliknya.

Kedudukan akta hibah dalam sengketa kepemilikan hak atas tanah adalah sebagai alas hak dalam peralihan perubahan hak atas tanah yang berbentuk akta autentik. Alas hak merupakan salah satu syarat bagi warga negara untuk mengajukan permohonan hak atas tanah, namun alas hak itu sendiri bukan hak atas tanah. Lembaga pendaftaran, tidak hanya semata-mata mengandung arti sebagai pemberi alat bukti kuat, namun juga menciptakan hak kebendaan. Hak kebendaan atas suatu benda yang berupa tanah terjadi pada saat dilakukan pendaftaran. Sebelum pendaftaran dilakukan maka hanya baru berupa milik, belum sebagai hak. Terkait demikian, maka salah satu asas penting pada hak atas tanah adalah asas publisitas demi terwujudnya kepastian hukum.

\section{DAFTAR PUSTAKA}

Abdul Kadir Muhammad, Hukum Perdata Indonesia (Bandung: Citra Aditya Bhakti, 2000).

Boedi Harsono, Hukum Agraria Indonesia (Sejarah Pembentukan Undang-undang Pokok Agraria,Isi, dan Pelaksanaannya) (Jakarta: Djambatan, 2003).

G.H.S. Lumbang Sutobing, Peraturan Jabatan Notaris (Jakarta: Erlangga, 1983).

Habib Adjie, Sanksi Perdata dan Administratif Terhadap Notaris Sebagai Pejabat Publik. Cet. 2, (Bandung: Refika Aditama, 2009).

Macpherson C.B., Pemikiran Dasar Tentang Hak Milik (Jakarta: Yayasan LBH Indonesia, 1978).

Munir Fuady, Hukum Kontrak (dari sudut pandang hukum bisnis), (Bandung: Citra Aditya Bakti, 1999).

Nindyo Pramono, Hukum Komersil (Jakarta: Pusat Penerbitan UT, 2003).

R. Subekti, Aneka Perjanjian (Bandung: Citra Aditya Bakti, 1995).

R. Setiawan, Empat Kriteria Perbuatan Melawan Hukum dan Perkembangan dalam Yurisprudensi, Varia Peradilan No. 16 Tahun II (Januari 1987).

Soerjono Soekanto, Pokok-Pokok Sosiologi Hukum (Jakarta: Raja Grafindo Persada, 2002). Urip Santoso, Pendaftaran dan Peralihan Hak atas Tanah. Cet. 2 (Jakarta: Kencana, 2010). 